short life he engaged in numerous activities, but the subjects in which he was chiefly interested were electrotherapy, hypnotism, functional nervous diseases, longevity and the reform of medical education. As a mental expert he took part in several famous trials and notably that of President Garfield's assassin Guiteaud, whose case he reported in the Journal of Nervous and Mental Disease of January 1882. Of his numerous other writings the most important are "Medical and Surgical Electricity" written in conjunction with A. D. Rockwell (1875), "Neurasthenia (Nervous Exhaustion) with Remarks on Treatment" (1879) and "American Nervousness : Its Causes and Consequences", which was translated into German. He also contributed many artieles to the North American Review in which he popularized scientific knowledge, and was the founder of the Archives of Electricity and Neurology, which had only a short existence $(1874-76)$. He was one of the originators of the National Association for the Protection of the Insane and of the American Neurological Society. $\mathrm{He}$ died on January 23, 1883.

\section{Preservation of Wild Geese and Wild Duck}

The Wild Birds (Ducks and Geese) Protection Bill, which passed its final stages in the House of Lords on May 2, and will come into force as an Act on August 1, marks a decided step forward in the efforts being made to conserve the world's stock of Anatidæ. During its passage through Parliament, the Bill has been strengthened by amendments put forward by the promoters, the International Committee for Bird Preservation (British Section). The Bill, when first introduced in November 1938, was framed with the view of securing its rapid passage as an unopposed measure; but as opposition was encountered the promoters, while compromising on certain points, were able to gain considerably on others. The main terms of the Bill in its final form are : the extension of the 'close season' for wild geese and wild duck (of any species whatsoever, the merganser and goosander only being excepted) from February 1 to August 11 ; the addition of wild geese of all species to the schedule; and the prohibition of import of wild geese and wild duck from February 1 to August 11. Heretofore wild duck have enjoyed the benefit of being scheduled birds (by the Act of 1880), that is, protected from owners and occupiers of land on their own land-during the close season-but wild geese have not. The new measure, therefore, greatly increases the protection afforded to wild geese. However, in order to safeguard the interests of farmers, for, in certain cases, willd geese are considered to damage crops, a clause gives power to county councils to apply to the Secretary of State for Home Affairs to remove wild geese from the schedule in any area in the county concerned.

County councils also have the right to make similar application to extend the shooting season for wild duck and wild geese on the shore and land contiguous to it to a date not later than February 21. This clause is admittedly a concession, but the duck it will affect are mainly widgeon. Though quite a number of widgeon nest in Scotland, their breeding season is during the second half of May, and the majority of birds are those passing through on their way north to breed, where the season is later still, usually not until June. Allowing these birds to be shot until a later date would not have so much deleterious effect as would the shooting of earlier nesting species. Further, county councils retain the right to make application to extend the statutory close season, but not, as heretofore, to diminish it. The prohibition of import of wildfowl during the breeding season is an extremely important point, for it cuts off the demand from the London market of ducks caught in decoys in certain European countries at this time. Thousands of duck have been caught annually in decoys on the Continent during the breeding season, and this has been a serious drain on the stock of European wildfowl; by means of the new Act this drain will now be effectively curtailed.

\section{Sir Ambrose Fleming and the Thermionic Valve}

Welcomed by the Provost (Sir Allen Mawer), Prof. R. O. Kapp and an appreciative audience, Sir Ambrose Fleming once again visited, on April 27, University College, London, where for more than forty years he occupied the chair of electrical engineering. The occasion was the formal presentation to the College by Mr. R. McV. Weston of a convenient exhibition case to hold early Fleming and other valves in the possession of the Electrical Engineering Department, including those presented recently by Mr. Weston and Sir Ambrose himself. After the case had been unveiled, with the appropriate aid of torch, photocell, valve amplifier and relay, Sir Ambrose gave a remarkably clear and vigorous address on the history of the valves displayed. The story began when he investigated the reason for a white line of clearer glass in the deposit of evaporated carbon from the filaments of early Edison-Swan lamps after many hours of use. He concluded that some of the carbon particles became charged and were driven off with high velocity from one end of the filament, throwing a 'shadow' of the other side of the hairpin loop on to the glass. Edison, in America, hung a metal plate within the loop, and found that when connected through a galvanometer to the positive end of the filament, a current flowed to the plate, but not when connected to the other end.

EDIson left the subject with the discovery of this effect; but Fleming continued his experiments, which led to the construction of a bulb containing a filament at each end. With one filament hot, negatively charged particles would flow through the bulb to the other filament, if the latter was a few volts positive, but not if negative. This was the first 'rectifying valve', and here Sir Ambrose left the work to concentrate on his teaching duties. It should be emphasized that this work was before the discovery of the electron by Sir J. J. Thomson. During the next decade, Sir Oliver Lodge, Marconi and others were 